\title{
Scientific Objectives and Observational Requirements of Spectrometers for Main Belt Comet 133P/Elst-Pizarro Exploration
}

WANG Weigang *a, ZHANG Hao ${ }^{b}$, LI Bicen a, YIN Jianjie a a Beijing Institute of Space Mechanics and Electricity, Beijing, China; b School of Earth Sciences, China University of Geosciences (Wuhan), Wuhan, China

$12^{\text {th }}$ international Conference on Space Optics 11-10-2018, Chania, Greece 


\section{Content}

- INTRODUCTION

- ANALYSIS OF MAIN BELT COMET 133P/ELST-PIZARRO

- DESIGN OF SPECTROMETERS FOR MAIN BELT COMET 133P/ELST-PIZARRO

- CONCLUSION 
- INTRODUCTION

- ANALYSIS OF MAIN BELT COMET 133P/ELST-PIZARRO

- DESIGN OF SPECTROMETERS FOR MAIN BELT COMET 133P/ELST-PIZARRO

- CONCLUSION 